\title{
Political Influence in Communal Elections with Emphasis on the Position of Independent Candidates in Slovakia
}

\author{
Xénia Domaracká ${ }^{1, *}$ \\ ${ }^{1}$ Matei Bell University, Banska Bystrica, Slovakia \\ ${ }^{*}$ Corresponding author. Email: domaracka.xenia@gmail.com
}

\begin{abstract}
The purpose of this article is to analyse the position and start point of independent candidates in the Slovak elections, with strong emphasis on municipal elections, where independent candidates have gradually gained a significant footing. A further aim of this paper is to show a possible connection between the municipal and general elections, with regard to the electoral system. We assume that in a majoritarian or a mixed system, independent candidates could gain more momentum, which could be beneficial for both the citizens and the state. Based on our previous experience and specific results of analyses, we have formulated a hypothesis: in communal or municipal elections, there is much more emphasis on regional interference than on reference to a political party". We would like to verify the hypothesis, whether citizens in municipal elections prefer independent candidates, as their mayors or deputies and derived from this, we propose to link the success of independent candidates in municipal policy with government policy, in order to highlight that interconnection of the voter and the respective representative could bring more advantages to the electoral system as a whole. By emphasising the citizens' leaning towards independent candidates without political affiliation, we would like to show that a more direct approach is needed in general elections as well. The aim of this article is to analyse the current situation of independent candidates in Slovak elections, and to look at the influence the current situation has on the political culture and the respective election results. The paper does not include the results of the 2020 general elections, as they do not show a strong influence of independent candidates, because of the fact that elections to the National Council of the Slovak Republic are still party-based. That is the main reason our research data ended in 2018. As long as specific methods are concerned, in this paper we chose to apply analysis, synthesis, scientific abstraction, mathematical statistics and critical analysis.
\end{abstract}

Keywords: Election, Electoral system, Municipal policy, Independent candidates.

\section{INTRODUCTION}

An election is generally understood as a matter of public (not private) interest. According to some authors ([1] Goodwin-Gill, 2006, Medvic, 2008), voting behaviour is such a versatile phenomenon, that any regularity, pattern and even causes cannot be found during the electoral act. Moreover, the diversity of political systems, electoral rules, political parties, as well as the political culture of the society and historical traditions make it impossible to generate theoretical postulates of

Research type: Research paper

JEL classification: K16 Election law; Z18 Public Policy voting behaviour applicable across countries ([2] Horváth and Šebík, 2015). Many times, the voter in municipal elections prefers her/his private interest. The voter usually thinks that she/he handles better and faster her/his personal affairs at the office with who she/he knowns, so she/he will vote for the respective candidate. We consider the choice of the candidate based on private relationships instead of selecting candidate based on expertise as a precedent. As an example, we can mention two candidates for the mayor of whom one is more qualified than the other with whom the voter has personal relation. He chooses the second candidate because his choice is influenced by ancestral injustice. These situations occur especially in 
smaller municipalities. According to Konečný ([3] 2006), the basic difference between municipal policy of towns and municipal policy of other, smaller municipalities is that in the most extensive territory with the importance of larger economic volumes and much more numerous and differentiated social structure of urban population it comes to stronger structuring of interests in which it is possible to distinguish the interests of the town and interests of the specific town district.

There are certain debates about changing the electoral system, as Slovakia is one of the few countries in Europe which does not use more districts within its general elections. The presence of electoral districts, their number and size create an important aspect of the relationship between the electoral system and the party system ([4] Kerekes et al, 2016). The idea which was repeated in most of the discussions was a majoritarian or mixed electoral system, which could bring representatives closer to the people by making them more accountable. However, the electoral system has not been changed and the country remained one electoral district ([5] Baboš - Világi, 2019). Other countries of the V4 changed their electoral system and use districts to ensure equal votes. The same system could be possibly applied in Slovakia as well. In Hungary, the electoral system experienced changes in 1994 and 2010. The aim of the change was to strengthen interest of the national parties in regional and local policy ([6] Gregor, 2017). In Poland, local authorities are one of the most important public institutions. The executive bodies are village and town mayors and presidents, who are chosen in a procedure of indirect elections ([7] Slobodzian, 2016). The lower house (Sejm) is represented by 460 elected deputies. There are 41 constituencies, each allotted between 7 and 19 seats. Each constituency provides a candidate list and members of that district vote on the candidates they want to elect. The Czech people vote for the candidates who will be members of Chamber of Deputies. 200 seats are divided between the candidates from 14 regions. Mandates of each party are divided based on d'Hondt method.

Good public policy begins in regions, towns, municipalities. If the town/municipality is developed, then the region, country is characterized as developed as well. There are many expert opinions on the reasons to change the electoral system of the Slovak Republic, where such a system is proposed in which the members of the National Council would directly represent a specific region. In practice, it means that the territory of the state would be divided into 4 counties and one separate district which would be formed by the capital city of Bratislava. The voters of each region would select representatives from the list of candidates of their region and vote for example out of 20 candidates of the respective region (currently the choice is made from 150 candidates). Candidates would be regional leaders who are personalities known by their voters, citizens who contribute to the development of their municipality/town/region/territory. The outcome of this change could be expectation of more active participation in both municipal and parliamentary elections.

A similar electoral system was approved and adopted in Hungary in 2011 after the elections of 2010. With the change, the principle of the equality of votes was to be ensured, so the districts had to be redrawn to be more equal. The country fixed this new electoral system with two issues: it introduced a single-round majoritarian model, one that ensures increased transparency, creates stronger governments capable of pursuing much-needed reforms and is easy to understand for the voters. On the other hand, the size of the parliament shrank to 199 members of which 106 are elected in singlemember electoral districts and remaining 93 qualifying from national party lists ([8] Kovács, 2018). Polish voters elect their bicameral parliament consisting of 460-member lower house Sejm and 100-member Senate. Both are elected for a four years period. The former is elected under proportional representation according to the $\mathrm{d}$ 'Hondt method whilst the latter is elected by plurality vote in single member districts, introduced by the Election Code in 2011 and first used in the election 2015 ([9] Jaskiernia, 2017). In the Czech Republic the Chamber of Deputies composes of 200 Deputies who are elected for four years. One of the main criteria is the number and size of electoral circuits. Electoral circuity for elections to the Chamber of Deputies is the electoral regions, which correspond to the territory of the higher selfgoverning territorial units (13 regions and the capital city of Prague). When elections are held, the 200 available mandates are first allocated among the electoral regions on the basis of the number of valid votes that were cast ([10] Office of the Chamber of Deputies, 2019).

\section{METHODOLOGY OF THE PAPER}

Regarding the methodology of this paper, we would like to focus our interest on the analysis of 
the current situation of the electoral system in Slovakia and its impact on the political culture and respective electoral results. We propose to link the success of independent candidates in municipal policy with government policy, in order to highlight that interconnection of the voter and the respective representative could bring more advantages to the electoral system as a whole. By emphasising the citizens' leaning towards independent candidates without political affiliation, we would like to show that a more direct approach is needed in general elections as well. The aim of this article is to analyse the current situation of independent candidates in Slovak elections, and to look at the influence the current situation has on the political culture and the respective election results. We would like to verify the hypothesis, whether citizens in municipal elections prefer independent candidates, as mayors or deputies. In order to verify this claim, we defined the hypothesis as follows: ,in communal or municipal elections, there is much more emphasis on regional interference than on reference to a political party". In this article, we assume, that there is a positive correlation between the number of independent deputies and the number of independent mayors. As long as specific methods are concerned, in this paper we chose to apply analysis, synthesis, scientific abstraction, mathematical statistics and critical analysis.

Analysis is generally a detailed examination of elements, ideas, or the structure of something. It belongs among the most significant scientific methods, as it can form a basis for discussion or interpretation. Synthesis is defined as the combination of ideas to form a theory, system, larger idea, point or outcome and is used for showing commonalities or patterns. Moreover, we can use synthesis and analysis at the same time, combine them and examine ideas to:

- show how commonalities, patterns, and elements fit together

- form a unified point for a theory, discussion, or interpretation

- develop an informed evaluation of the idea by presenting several different viewpoints and/or ideas.

In fact, scientific abstraction means induction of ideas or the synthesis of particular matters into one general theory about something. An abstraction can be wrapped into a compression process, mapping multiple different parts of constituent data to a single fragment of abstract data; based on similarities in the constituent data. This conceptual pattern underlines the inherent equality of both constituent and abstract data, thus preventing problems arising from the distinction between what is "abstract" and what is "concrete". Apparently, the process of abstraction involves the identification of similarities between objects, and the process of associating these objects with an abstraction. The method of mathematical statistics is concerned with the planning of studies, mainly with the design of irregular experiments and with the planning of surveys using random sampling. The introductory analysis of the data usually happens according to the study protocol specified prior to the study being conducted. The data derived from a study can also be examined to acknowledge secondary hypotheses inspired by the initial results, or to suggest new studies. A secondary analysis of the data from a planned study applies means from data analysis, and the process of doing this is mathematical statistics. Finally, a critical analysis represents subjective writing because it expresses the writer's opinion or evaluation of a text. Analysis means to break down and study the parts. Writing a critical paper usually requires two steps: critical reading and critical writing.

\section{THE CURRENT ELECTORAL SYSTEM OF THE SLOVAK REPUBLIC}

The Slovak Republic is an inland country with 5.4 million of inhabitants. The country composes of 8 counties, 79 districts and 2883 municipalities. According to the Slovak Constitution, the power in the state is divided into executive, legislative and judicial power. Executive power is performed by the President of the Slovak Republic and the Government of the Slovak Republic, which is appointed by the President. Legislative power is vested in the hands of the National Council of the Slovak Republic (The Constitution of the Slovak Republic). Members of National Council of the Slovak Republic perform representative power based on the representation of the citizens by the citizens, who were elected in the democratic elections. Judicial power is vested in independent courts. The Slovak Constitution mentions the right to vote and not a duty to vote, which means that elections cannot be obligatory. The electoral system is a summary of legislative, technical and organizational rules by which the will of the people is trasferred into mandates ([11] Petöcz and Chytilek, 1997). 
In the Slovak legal order, there are various types of elections. The right to vote is a basic principle of any democracy. Participation in elections to the National Council of the Slovak Republic is universally higher than in the other types of elections. Voter turnout in general elections was $59.11 \%$ from total number of voters in 2012. In 2016 there was a slight increase about $0.71 \%$ to $59.82 \%$. In 2020, in the most recent general elections, the voter turnout achieved as much as $65,80 \%$, which was quite surprising, but a lot of non-voters came to vote in these elections. In the second round of the presidential elections which held in 2014 participated $50.48 \%$ of voters. In 2019 in the second round of presidential elections participated $41.79 \%$ which shows decrease of interest about presidential elections in the second round about $8.69 \%$. In 2013, there were elections of the bodies to the local government. There was a participation of $17.29 \%$ eligible voters and in 2017 the participation increased about $12.66 \%$. In 2014, at the elections to the European parliament participated $48.34 \%$ of eligible voters and in 2018 slight increase was shown (about $0.33 \%$ ). In 2014 there were elections to the municipalities. $13.05 \%$ of the eligible voters participated in 2014 and in 2018 the participation of the voters increased about $9.69 \%$ to $22.74 \%$. ([12] Leff, 2018)

The participation of voters per each type of election is shown in "Figure 1".

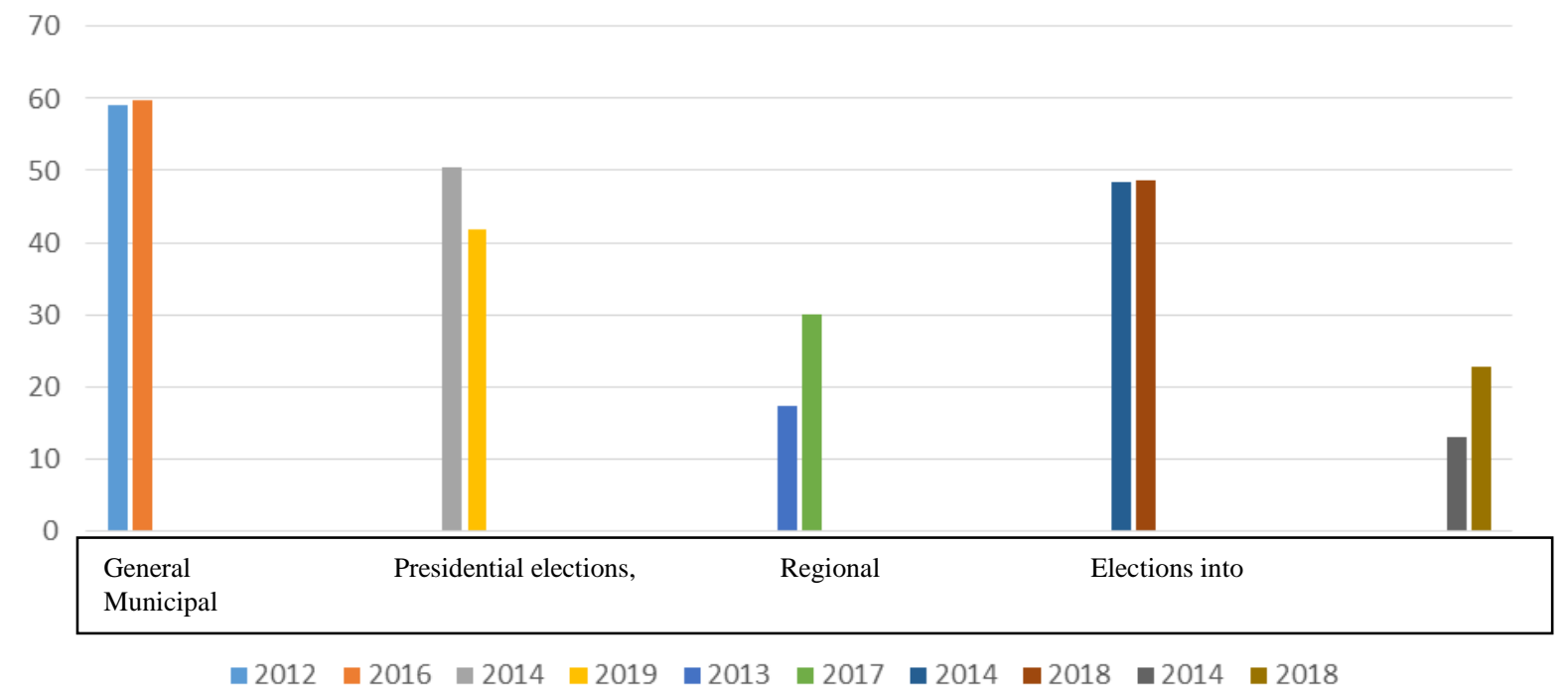

Figure 1 Participation of voters per type of elections in SR (in \%).

General elections to the National Council of the Slovak Republic are considered to form a basic principle of democracy in the country. The Slovak legal electoral framework does not change very often and in each case, there is a question of equivalence and efficiency. It is necessary to avoid doubts about its benefit for the voters or authorities of the political power.

The change of the Electoral Code from 1998 concerned the fact that the Slovak Republic became a one-mandate electoral district, which caused according to [13] Lebovič, that (1999):

- the initial 4 electoral counties were substituted by one electoral district in which 150 members are elected by the voters, a Source: Statistical Office of SR and own graphic processing.

- active and passive right could be revoked to the inhabitant in a case of imprisonment,

- private media were excluded from the election campaign and if they participate on the elections then they can be penalized,

- only the public broadcaster which was strongly influenced by the ruling party HZDS (Hnutie za Demokratické Slovensko - Movement for a Democratic Slovakia) could participate in the electoral campaigns,

- local government, which controlled the course of the elections came under control of the state government,

- inner-coalition $5 \%$ clause, 
- electoral moratorium for publishing the polls was 14 days before elections,

- political parties had to finish the campaign 48 hours before elections,

- restriction of democratic dialogs of all parties.

Dančišin (2012) [14] criticizes the setting of the Slovak electoral system because it can create a situation where voters are harming the party they vote for. According to his opinion, the change in electoral system does not automatically increase the electoral participation, cure the apathy of potential voters nor remove the disgust of politicians and corruption. The change will mean that when a voter decides to vote, he will be sure that his vote will not harm the preferred party.

\section{POSITION OF INDEPENDENT CANDIDATES IN VARIOUS ELECTORAL SYSTEMS}

The development of the country is a consequence of the development of the region, because from there the development of the state stems. "High policy" starts at the level of municipal policy. Elections to bodies of regional selfgovernments in Slovakia do not usually attract much attention of the expert community, media, but not even the voters ([15] Marušiak, 2018). Today we witness a growing apathy of people towards politics not only in Slovakia, but also in many other EU countries. It seems that the enthusiasm towards democracy, that followed the fall of communism, has faded away. We must not forget that democracy cannot be democracy without one of its main attributions, elections. Elections give opportunity to every person not only to affect public affairs but also to take partial responsibility for what is going on in the republic as well as in society ([16] Mikuš and Gurňák, 2014).

Current political aversion inherently ends in the need of change of the electoral system and marginalisation of political parties' influence. Štefančík [17] (2005) says that in a proportional system, non-party candidates must also be on the list of the political party but in the majoritarian system such condition does not exist. Purely theoretically, non-party candidates can fill all parliamentary seats. An example that demonstrates the convenience of the majority system for independent candidates is the composition of the Czech Senate. From 81 senators about 20 do not report to any political party. If we would like to find the same example without leaving the territory of the Slovak Republic, then we can analyse the elections of mayors of Slovak towns and municipalities. If the members are criticized for their political independence, it can happen that in a majoritarian system, this will be an important benefit. If each Member would be elected directly in the region, his most important goal would be to make the greatest profit to this region. The more he succeeds, the more he will strengthen his position in the region and with it the chance to be re-elected in the National Council of the Slovak Republic. If independent members are convinced that they will not be re-elected because of abandonment of the party, in the majoritarian system this would be the opposite. More wastewater treatment plants, sports halls, road and industrial parks built in the region, the more chance they have of staying in the parliamentary seat after the elections. The preference of independent candidates is also reinforced by the fact that citizens are disgusted with politics and political parties which repeatedly cause political scandals. Citizens prefer to promote a new impartial face in politics rather than politics associated with causes at regional or national level.

Strengthening the development of the region must be an essential priority to any politician. The political parties and their leaders play an important role in the horizontal as well as vertical models of governance in the democratic framework. They represent the will of parts of the population, as well as they are structured to provide the ideas and reasons for future society enhancement and public development. If the parties fail to deliver their basic legacy it has great consequences for the whole society ([18] Mihálik, 2017). The voter expects to be represented by a leader who is connected to the territory she/he represents. In a state like Slovakia, it is necessary to change the electoral system to majoritarian, which means strengthening regions, providing the possibility to be a voter's representative as well as a candidate without political affiliation. The need of change is visible e.g. by the analyse of the municipal elections in which the independent candidates are elected as mayors. "Figure 2" and "Figure 3" shows the results of municipal elections for 2014 and 2018.

\section{FACTORS AFFECTING VOTER TURNOVER}

The execution of the public power is divided to state administration and self-government. State administration means execution of public power by 
the state and the self-government means public administration executed by the territorial selfgovernment. The territorial self-government is a phenomenon which is closest to the citizens, they are linked with its activity and it influences their lives "from the front line". Citizens are pillars of the public power execution by exercising their right to vote through elected representatives.

Many studies and analysis examine which factors affect voter turnover. It is possible to say that "citizens' participation in governance should be understood as a process of influencing decisions in self-government matters by citizens" ([19] Hamalová, Belajová, Šebová, 2011, p. 39). Lysina [20] (2012) mentioned two approaches in his study that influence the behaviour of voters - sociological and socio-psychological. According to the sociological approach, the voter is influenced by long-term allocation in the social environment (links to the social environment and affection for leaders who defend the interests of a selected social group). Socio-psychological approach shows the long-term and individual emotional relation of the citizen to the political party. Gyárfášová a Šlosiarik [21] (2016) consider volatility to be a more stable feature of voting behaviour in Slovakia, from a long-term point of view, but they highlighted a second phenomenon, namely the high mobilization of first-time voters and former non-voters. Kováčová [22] (2016) dealt with the results of elections to the National Council of the Slovak Republic and voter behaviour in 2016. According to the election results she confirmed variability in voter behaviour and voter turnover. According to the author's opinion, the vast majority of voters do not incline to rational decision-making. By voters dominated the value choice and they do not take into account the pre-election preferences of the parties and are stable in their voting behaviour. Smolko a Smolková [23] (2017) analysed on the sample of voters the influence of political marketing on the behaviour. Based on results of their research they concluded that in both municipal and as well as in parliamentary elections the voters expect marketing communication by political entities. In municipal elections $30 \%$ of the voters and in parliamentary elections $35 \%$ of voters decide based on the goals and messages communicated.

Political entities operating in the Slovak Republic have probably lost their credibility, acting as if they were not interested in citizens. As long as populistic solutions are taken, they do not solve the essence of the population's problem. Citizens of the country must perceive that elected political entities work in their interest. In the Slovak Republic, the vision of the country from the long-term perspective is missing. We assume that the vision of the country is as important as the factor of national identity. According to [24] Bačová (1997), national identity is a matter of individual decision, is considered as rational response to the demands of the situation of social pressures from their own or other community. If the country does not have identity, then it does not have character. The identity can be obtained by natural adoption. Relationship with the territory, and the change of citizens' attitude to the territory (which is automatically linked with the acceptance of identity) are important factors for the development of any municipal policy. Anyhow, we do not understand identity as a constant quantity.

\section{RESULTS OF MUNICIAL ELECTIONS WITH REGARD TO THE POSITION OF INDEPENDENT CANDIDATES}

From "Figure 2" and "Figure 3", we can see the trend of municipal policy. Majority of elected mayors are independent candidates. This indicates a possible failure of the political power of the system. Candidates for position of mayors who are not delegated by any political entity are more successful in the municipalities and smaller towns because voters know their personal profile. Based on the study of European Parliament ([25] 2013) independent candidates face tremendous obstacles in elections because they compete with political parties - large-scale organizations, designed for the purpose of winning political office. Parties with lower voting costs, allow individual candidates to benefit from association with like-minded others, and provide candidates with organizational and financial support. Independent candidates are in such a position to benefit from technological changes driving the personalization of politics. The reduced importance of party machines in political campaigns of the information era places independent candidates on a more equal footing with party candidates.

In regional and larger cities, voters are often misled by political marketing. In the campaigns the parties promise to the voters' strategies and projects which are not feasible in practice e.g. decrease of the regional disparities, allocation of sources, decrease of social conflicts and others. Once they are elected, the pre-election promises will not 
become a reality. This finding is disappointing for the voter.

In municipal elections held in 2014, 2 years after elections to the National Council, the voters gave the highest number of valid votes to independent candidates ("Figure 2"). In the 2014 elections, independent candidates took 1104 mayoral posts ( 37.95 percent) and 6000 seats in the municipal councils (28.91 percent). The turnout in the municipal elections oscillates around 50 percent of eligible voters (Minarechová, [26] 2018).

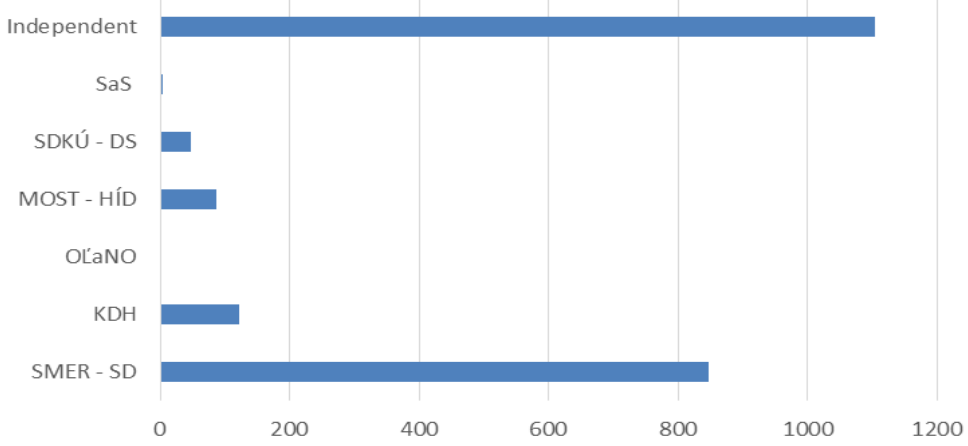

Figure 2 Number of mayors according to the political entities in 2014.

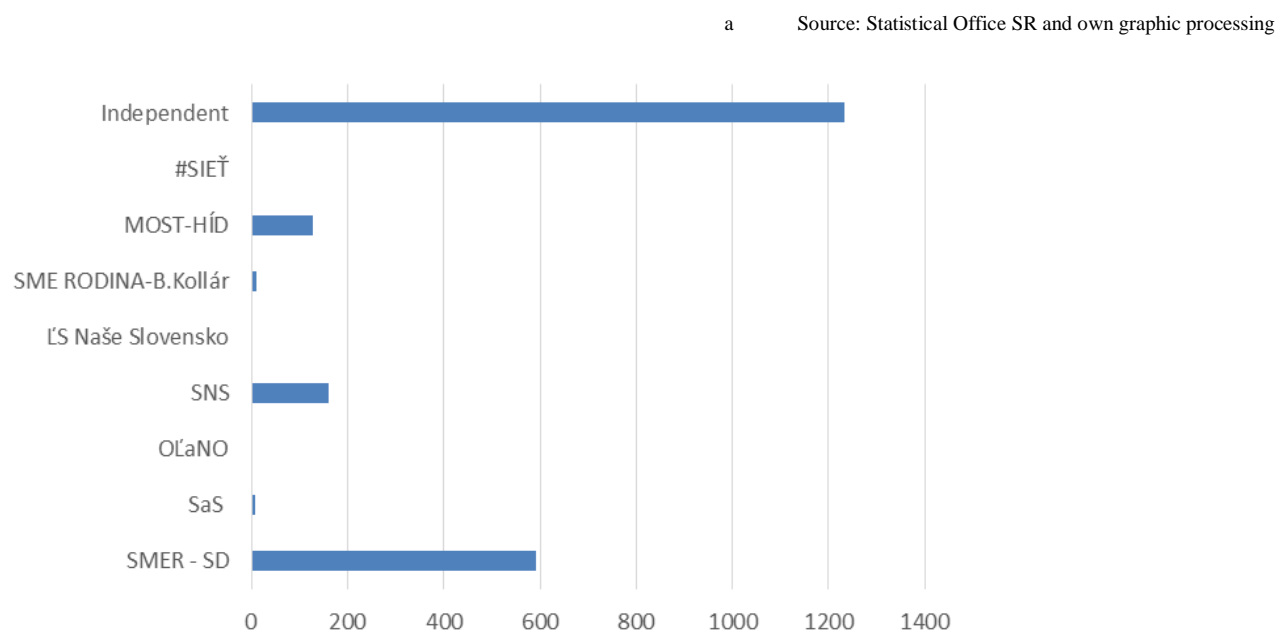

Figure 3 Municipal elections 2018.

In the municipal elections for period of 2018 2022, there were elected about 128 independent mayors more than for the previous period of 2014 2018 ("Figure 3"). The parties saw the results as follows: coalition parties gained more than $36 \%$ of mayors, opposition parties less than $10 \%$, statistically the winner with 592 mayors was SMER-SD. We can see the drop from level of $30 \%$ in previous elections to $20 \%$. Generally, appeal of coalition parties was more dominant on countryside rather than cities. Growing trend of independent candidates was re-confirmed ([27] CEC, 2018). The similar political situation as in Slovakia is observed in other countries of V4 as well. In Polish local government elections, which were held in 2014, the a Source: Statistical office SR and own graphic processing

independent candidates for councillors took more than $70 \%$ of mandates. During local elections in 2018, in many places in Poland, the ruling party lost the power and has no influence at the local government levels. Based on the results of the election it is possible for opposition parties to obtain the majority if they can be united. According to the election results there is a need for some changes of the role and shape of the selfgovernment. Through the changes in the law the role of the self-government should be more important and influence the functioning of the country ([28] Zientarski, 2019). In Hungary over $77 \%$ independents serve as mayor in period of 2014-2019. The members of alliance Fidesz-KDNP 
serve as mayor in 614 municipalities and members of other parties and party alliances in 116 municipalities ([29] Evera, 2015). Voters in the Czech Republic elect the members of municipal council. In 2018 elections more than $56 \%$ of elected members were from Alliance of independent candidates and $10 \%$ were independent candidates. The remaining part contains from the members of parties. The mayor is elected directly by the municipal council and the most of the mayors are independent candidates ([30] Czech Statistical Office, 2019).

The argument of an unambiguous surpass of independent candidates above others has not been affirmed in each county. It is interesting to follow, how the number of mayors changes - the candidates of more parties - in the West-East direction.

Table 1. Number and share of elected mayors according to particular political subjects per county -2018 elections

\begin{tabular}{|c|c|c|c|c|}
\hline Code of the county & Title of the country & Political subject & Number of mayors & Share of mayors in \% \\
\hline 1 & \multirow{4}{*}{ Bratislava county } & Independent & 60 & 68 \\
\hline & & Coalition & 8 & 9 \\
\hline & & Opposition & 18 & 21 \\
\hline & & Other & 2 & 2 \\
\hline 2 & \multirow{4}{*}{ Trnava county } & Independent & 147 & 59 \\
\hline & & Coalition & 46 & 19 \\
\hline & & Opposition & 36 & 14 \\
\hline & & Other & 20 & 8 \\
\hline \multirow[t]{4}{*}{3} & \multirow{4}{*}{ Trenčín county } & Independent & 142 & 52 \\
\hline & & Coalition & 107 & 39 \\
\hline & & Opposition & 19 & 7 \\
\hline & & Other & 6 & 2 \\
\hline \multirow[t]{4}{*}{4} & \multirow{4}{*}{ Nitra county } & Independent & 154 & 44 \\
\hline & & Coalition & 145 & 41 \\
\hline & & Opposition & 48 & 13 \\
\hline & & Other & 6 & 2 \\
\hline \multirow[t]{4}{*}{5} & \multirow{4}{*}{ Žilina county } & Independent & 184 & 59 \\
\hline & & Coalition & 91 & 29 \\
\hline & & Opposition & 30 & 10 \\
\hline & & Other & 5 & 2 \\
\hline \multirow[t]{4}{*}{6} & \multirow{4}{*}{$\begin{array}{l}\text { Banská } \\
\text { county }\end{array}$} & Independent & 181 & 35 \\
\hline & & Coalition & 213 & 42 \\
\hline & & Opposition & 83 & 16 \\
\hline & & Other & 35 & 7 \\
\hline \multirow[t]{4}{*}{7} & \multirow{4}{*}{ Prešov county } & Independent & 185 & 28 \\
\hline & & Coalition & 336 & 51 \\
\hline & & Opposition & 115 & 18 \\
\hline & & Other & 21 & 3 \\
\hline \multirow[t]{4}{*}{8} & \multirow{4}{*}{ Košice county } & Independent & 179 & 39 \\
\hline & & Coalition & 167 & 36 \\
\hline & & Opposition & 104 & 23 \\
\hline & & Other & 10 & 2 \\
\hline
\end{tabular}


Table 2. Number and share of elected mayors according to particular political subjects for the whole state elections 2018

\begin{tabular}{|l|l|l|}
\hline \multicolumn{1}{|c|}{ Political subject } & \multicolumn{1}{|c|}{ Number of mayors } & \multicolumn{1}{c|}{ Share of mayors in \% } \\
\hline Independent & 1232 & 42 \\
\hline Coalition & 1113 & 38 \\
\hline Opposition & 453 & 16 \\
\hline Others & 105 & 4 \\
\hline
\end{tabular}

\section{RESEARCH RESULTS}

From "Table 1" and "Table 2", we can derive, that in municipal elections, citizens do not expressly care about the political affiliation of the respective candidates. In "Table 1 " we can see, that citizens vote usually with reference to the political leader. They vote according to political affiliation only because of the fact, that they do not have any preferentially chosen candidate, but they do want to vote. In the end, they vote in terms of the political party, with the programme of which they sympathise and can identify themselves with. Citizens do not prefer political dimensions, although in the last municipal elections, the institution of wide party coalitions was formed in a significant manner. Political lists of candidates are often formed on the basis of centralisation without the assurance of advancement among the higher political position in the National Council of the Slovak Republic. On the other hand, they certainly are some examples. Richard Raši, former Vice Prime Minister, entered higher politics from municipal politics, as he was the mayor of Košice, the second largest city in the Slovak Republic. In general, independent candidates often decide about their candidacy themselves, or at the suggestion of a group of citizens, who advise them to do so. When we consider our key argument, it is safe to say that the number of independent candidates has been increasing. Therefore, it would be more than appropriate, that these independent candidates, who in many cases represent expert public community, or a change from below, participate in the creation of municipal, as well as national politics. In many cases we can observe that citizens do not understand the competences of municipalities, and that a municipality in fact does not have as many options to influence the development of foreign investments in the regions, or employment, the rise of regional GDP, or the development of traffic infrastructure. If these candidates could gain votes also at national level, they could influence the development of a respective region and thanks to that, the development of a respective territory.

\section{CONCLUSION}

Citizens are, by no means, ignorant about public matters. The president is the highest representative of the country, and the mayor/member is the highest representative of the town/municipality. The councils approve strategic documents, concepts, projects in which the public participates. Decisions of the municipal councils and mayors are decisions of long-term nature affecting longer period of the life of the town/municipality. The right to vote is a free decision of everyone, which means each voter. Daily duties and worries put interests of the public matters on another track. Region means firstly our home. Improvement of our region can be compared to the improvement of our homes. If we build, modernize our homes, we are likely to live in it happily. Successful changes are moving us forward and attract new and new challenges. People often do not realize how much power they obtain. Their power from the municipal policy point of view means the right of choice. The election of bodies of municipal self-governments is the closest to people because it is directly linked with their life. A well elected mayor and members of local council are assumptions of progressive development. In case of a wrong choice, there is a risk of increasing regional disparities manifested by the archaic municipality with minimalization of progress and zero vision for the future. If the electoral system into the National Council of the Slovak Republic would be changed, a stronger emphasis on the representatives' personality and achievements would be put. If each Member of the National Council would be elected directly by her/his own region, her/his most important goal would be to make the greatest profit to this region. This could have numerous benefits, both for the region and the overall state as well. Because of these facts, we have verified the hypothesis of our 
paper, as we have proved that citizens usually chose their representatives (when they have the possibility to choose between party affiliation and personality) according to personal achievements, successes, attitudes, views etc. of the respective candidate. If this could be transferred into state-level elections, voters could also apply a different method of choosing their own candidate, not relying only on party policy and party affiliation. Overall, we think that a more responsive and more active approach could enter Slovak politics after establishing a more personal electoral system.

\section{AUTHORS' CONTRIBUTIONS}

This paper is independently completed by Xénia Domaracká.

\section{REFERENCES}

[1] Goodwin-Gill, G. S. (2006) Free and Fair Elections. Ženeva: Inter-Parliamentary Union, 2006. 214 s. ISBN 9789291422777

[2] Horváth, P. - Šebík, K. (2015) Voting behavior and municipal elections 2014 in Slovakia. In: Slovak Journal of Political Science, issue: 02/2015, p. 93 - 113

[3] Konečný, S. (2006) Komunálna politika. Bratislava: Mayor, 2006. 143 s. ISBN 80969133-2-8.

[4] Kerekes et. al (2019) The Slovak 2016 Party System Eathquake. Could a slight electoral reform help? Sociológia 51, 2019, č. 1

[5] Baboš, P. - Világi, A. (2019) Consequences of Electoral reforms in Slovakia: Experimental Study. Working Papers in Sociology 1/2019. Institute for Sociology of SAS. ISSN 24536970

[6] Gregor, A. (2017) Electoral rules and fiscal outcomes - a regression discontinuity analysis of Hungarian municipal finances.

[7] Slobodzian, B. (2016) Polish electoral system to self local government - changes and effects. In: Slovak Journal of Political Sciences, Volume 16, 2016, No. 3 266-281 p.

[8] Kovács, J. (2018) Here`s how Hungary`s electoral system works and why it was changed in 2011. [online] [accessed 29 July 2019]. Available from internet: http://abouthungary.hu/blog/heres-how- hungarys-electoral-system-works-and-why-itwas-changed-in-2011/

[9] Jaskiernia, J. (2017) The development of the Polish party system: a perspective of the parliamentary elections results. Polish Political Science Yearbook vol 46 (2) (2017) 227-246 p. ISSN 0208-7375

[10] Office of the Chamber of Deputies of the Parliament of the Czech Republic. (2019) Parliamentary election [online] [accessed 29 July 2019]. Available from internet: http://public.psp.cz/files/okv/en_Parliamentary _elections.pdf

[11] Petöcz K. - Chytílek, R. et al. (1997). Fundamentals of democratic electoral systems. Bratislava: IVO, 1997. 84 s. ISBN 80-9677393-3

[12] Leff, C. (2018) The Czech And Slovak Republics: Nation Versus State. Londýn: Routledge, 2018. 320 s. ISBN 9780429965241

[13] Lebovič, P. (1999) Slovak elections 98: Who? Why? How?.1. Bratislava: Inštitút pre verejné otázky 1999. ISN 80-88935-04-4

[14] Dančišin, V. (2012) Electoral legitimacy in crisis. In: Crisis in politicspolitics in crisis? Prešov: University of Prešov in Prešov, 2012. 144 p. ISBN 978-80-555-0692-0

[15] Marušiak, J. (2018) Regional election in Slovakia - a New Reformation of the Slovak political scene? Contemporary European Studies 1/2018 $25-46$ p.

[16] Mikuš, R. - Gurňák, D. (2014) Electoral system of Slovakia - Perspective of Political Geography. Journal of the Geographical Institute „Jovan Cvijic“ Serbian academy of sciences and arts, vol. 64(1) (79-92)

[17] Štefančík, R. (2005) Majority electoral system in Slovakia? Slovak Political Science Review 04/2005. [online] [accessed 25 October 2019]. http://sjps.fsvucm.sk/Articles/05_4_2.pdf

[18] Mihálik, J. (2017) The Electoral Aftermath: New Wave Populism and Radicalism in Slovakia. In: Current trends and Public administration. Uherské Hradište, 2017. 9 p. ISBN: 978-80-906614-5-5

[19] Hamalová, M. - Belajová, A. - Šebová, M. (2011) Municipal economy and politics. 1. 
vyd. Bratislava: Sprint dva, 2011. 259 s. ISBN 978-80-89393-38-1

[20] Lysina, O. (2012). Turnout - crisis of society. In: Crisis in politics-politics in crisis? Prešov: University of Presov, 2012. s. 153 ISBN 97880-555-0692-0

[21] Gyarfášová, O. (2018) The fourth generation: From Anti-Establishment to Anti-System Parties in Slovakia. In: New Perpectives. Interdisciplinary Journal of Central \& East European Politics and International Relations. Vol. 26, No. 1/2018 109 - 133 p.

[22] Kováčová, N. (2016). Specifics of voting behavior in parliamentary elections in 2016 . [online] [accessed 28 September 2019]. Available from internet: https://revue.vsdanubius.sk/sites/default/files/ Kov\%C3\%A1\%C4\%8Dov\%C3\%A1_0.pdf

[23] Smolko, S. - Smolková, E. (2017). The influence of marketing in politics on voter behavior. [online] [accessed 28 September 2019]. Available from internet: https://www.mins.sk/vplyv-marketingu-vpolitike-na-volicske-spravanie/?print=pdf

[24] Bačová, V. (1997) Primordial versus Instrumental Basis of Ethnic and National Identity, Czechoslovak Psychology, 41 (3), $303-313$

[25] European Parliament (2013) Independent candidates in national and European elections. [online] [accessed 10 July 2019]. Available from internet: http://www.europarl.europa.eu/RegData/etude s/etudes/join/2013/493008/IPOL-

AFCO_ET(2013)493008_EN.pdf

[26] Minarechová, R. (2018) 5 most significant results of the municipal elections. [online] [accessed 10 July 2019]. Available from internet:

https://spectator.sme.sk/c/20958942/5-thingsyou-should-know-about-the-municipalelections.html

[27] CEC Government relations (2018) Slovakia: 2018 Municipal election results. [online] [accessed 10 July 2019]. Available from internet: http://cecgr.com/cecanalyses/slovakia-2018-municipal-electionsresults/
[28] Zientarski, P. (2019) The assessment of effects of local government elections in Poland in 2018. Regional Formation and Development Studies. Vol. 1 (27) 2019. 110-122 p. ISSN 2029-9370

[29] Evera, S. (2015) Guide to Methods for Students of Political Science. Ithaca: Cornell University Press, 2015. 144 s. ISBN 9780801454448

[30] Czech Statistical Office (2019) Municipal councils 2018. [online] [accessed 29 July 2019]. Available from internet: https://www.volby.cz/pls/kv2018/kvs?xjazyk= $\mathrm{CZ}$ 